Images in...

\title{
Not your typical pneumonia!
}

\author{
Laurence J Glancz, ${ }^{1}$ Amita Sharma, ${ }^{2}$ Peter Taylor ${ }^{3}$ \\ 1'Department of Neurosurgery, Hurstwood Park Neurological Centre, Haywards Heath, UK; \\ ${ }^{2}$ Department of Radiology, University Hospital Lewisham, London, UK; \\ ${ }^{3}$ Department of Vascular Surgery, St. Thomas' Hospital, London, UK
}

Correspondence to Laurence J Glancz, laurenceglancz@doctors.org.uk

\section{DESCRIPTION}

A 52-year-old gentleman presented to accident and emergency with a 1 -week history of sore throat. He had felt generally unwell and feverish the day prior to admission with a cough productive of yellow sputum. On examination he looked lethargic, had a temperature of $38^{\circ} \mathrm{C}$ and was tachycardic. Medical history included coarctation of the aorta repair in adolescence which subsequently became aneursymal. This was treated with endovascular thoracic aortic stent insertion 15 months prior to admission. Chest radiograph (figure 1A) demonstrated a left upper-lobe consolidation and an air-fluid level in the adjacent aorta. Urgent CT (figure 1B) confirmed an air-fluid level within the aneurysm sac. He was treated for aortic stent infection and associated pneumonia with broad-spectrum intravenous antibiotics. Given the complicated thoracic surgical history, we elected for a conservative approach with CT-guided transpulmonary drainage of the collection via the left posterior thoracic wall and concomitant insertion of a prophylactic chest drain. Approximately $25 \mathrm{ml}$ of pus was aspirated, which grew Staphylococcus aureus and Group A $\beta$-haemolytic Streptococcus. The aortic aneurysm sac drain was flushed on a daily basis. Antibiotics were rationalised to intravenous clindamycin (penicillin allergic) for 3 weeks. He was discharged home 1 month after admission and remains well on oral antibiotics.

Thoracic aortic stent infection is an uncommon but serious complication of endovascular insertion. ${ }^{1}$ To our knowledge, this is the first case of it presenting as pneumonia. Although the literature favours surgical rather than conservative management of the condition, ${ }^{1}$ we cite another case of successful conservative treatment.

\section{Competing interests None.}

Patient consent Obtained.

\section{REFERENCES}

1. Ducasse E, Calisti A, Speziale F, et al. Aortoiliac stent graft infection: current problems and management. Ann Vasc Surg 2004;18:521-6.
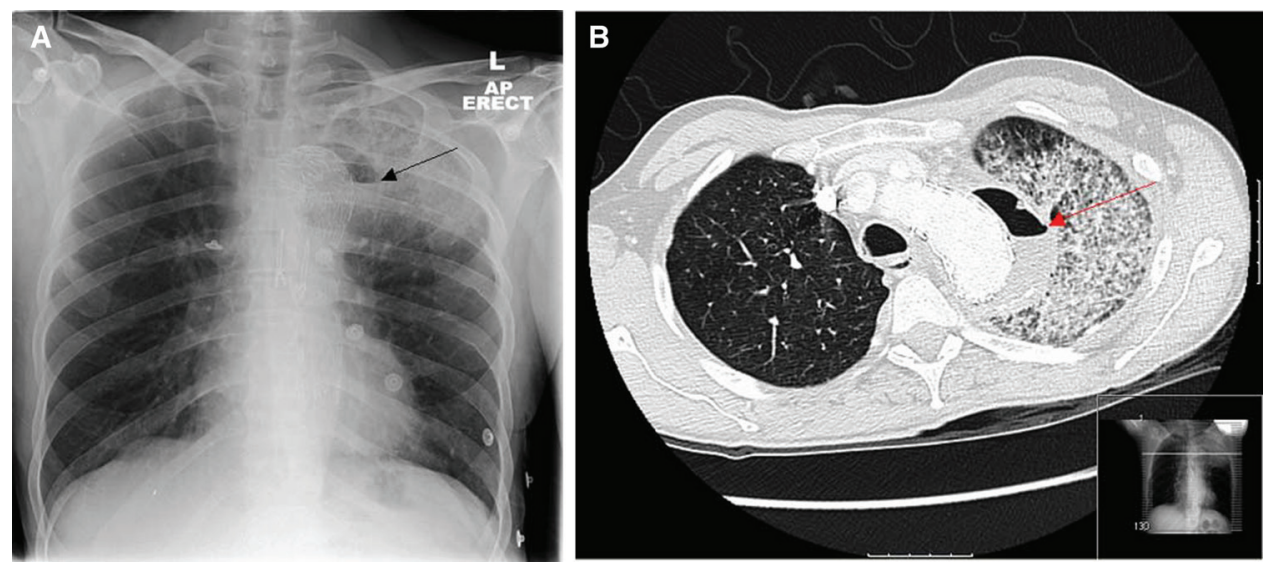

Figure 1 (A) Chest radiograph; (B) CT chest. 


\section{BMJ Case Reports}

This pdf has been created automatically from the final edited text and images.

Copyright 2011 BMJ Publishing Group. All rights reserved. For permission to reuse any of this content visit http://group.bmj.com/group/rights-licensing/permissions.

BMJ Case Report Fellows may re-use this article for personal use and teaching without any further permission.

Please cite this article as follows (you will need to access the article online to obtain the date of publication).

Glancz LJ, Sharma A, Taylor P. Not your typical pneumonia!. BMJ Case Reports 2011;10.1136/bcr.02.2011.3844, date of publication

Become a Fellow of BMJ Case Reports today and you can:

- Submit as many cases as you like

- Enjoy fast sympathetic peer review and rapid publication of accepted articles

- Access all the published articles

- Re-use any of the published material for personal use and teaching without further permission

For information on Institutional Fellowships contact consortiasales@bmjgroup.com

Visit casereports.bmj.com for more articles like this and to become a Fellow 